\title{
Walled towns as defensive cultural landscapes: a case study of Alanya - a walled town in Turkey
}

\author{
B. Tülek \& M. Atik \\ Faculty of Agriculture Department of Landscape Architecture, \\ Akdeniz University, Turkey
}

\begin{abstract}
Walled towns have been influenced by the natural features that surround them but also by the cultures that inherit and shape the landscape. Understanding walled towns with heritage and cultural landscape value is important for their integrated management and protection. The aim of this paper is to evaluate Alanya Walled Town, Turkey with ecological, cultural, economic and social dimensions and to discuss how such defensive foundations can be analysed in a systematic and multidimensional way as a heritage landscape but also as a historic settlement.

Keywords: walled towns, heritage, conservation, European Walled Towns (EWT), Alanya Castle.
\end{abstract}

\section{Introduction}

Walled towns are a kind of settlement that are built adjacent to, within or surrounded by a castle. They are also a type of cultural landscape of heritage value that shows us what kind of interactions proceed between humans and their natural and cultural environment. Because they have key heritage values, the association European Walled Towns (EWT) was set up as an international forum to promote the mutual interests shared by walled towns in Europe. Today there are 153 towns known from 27 countries and walled towns from Azerbaijan, Spain and Yemen are already in the UNESCO World Heritage List.

Anatolia has been located between the continents of Asia and Europe having 550 fortified walled towns of which Diyarbakır, Kütahya, Alanya, Osmangazi, Bursa, Eğirdir, Gaziantep, Karadeniz Ereğli are already a member of EWT. 
Alanya, formerly Alaiye, was located in ancient Pamphylia and Cilicia regions on the southwest Mediterranean coast of Turkey. The town has been an important stronghold for many Mediterranean-based empires, including the Ptolemaic, Roman, Byzantine, Seljuk's and Ottoman Empires which was typically a Seljuks city with Red Tower, Shipyard and the Castle.

The aim of this paper is to evaluate some walled towns of ETW and of Alanya Castle Town, Turkey analysed with regard to ecological, cultural, economic and social dimensions. Further assessment will be made on how such defensive foundations can be analysed in a systematic and multidimensional way as a heritage landscape but also a historic settlement. A closer connection between past and present and understanding of walled towns with heritage and cultural landscape value can help their integrated management and protection.

\section{Findings}

\subsection{Castles and Anatolian castles}

The word castle is derived from the Latin word castellum which is a diminutive of the word castrum, meaning "fortified place". The Old English castel, Old French castel or chastel, French château, Spanish castillo, Italian castello, and a number of words in other languages also derived from castellum $[1,2]$.

In its simplest terms, the word 'castle' accepted amongst academics is "a private fortified residence" [3]. This contrasts with earlier fortifications, such as Anglo Saxon burhs and walled cities such as Constantinople and Antioch in the Middle East; castles were not communal defences but were built and owned by the local feudal lords, either for themselves or for their monarch [4]. Feudalism was the link between a lord and his vassal where, in return for military service, the lord would grant the vassal land and expect loyalty [5]. In the late 20th century, there was a trend to refine the definition of a castle by including the criterion of feudal ownership, thus tying castles to the medieval period.

Castles were used for a range of purposes, mainly for defence as military base, administrative, and domestic. Norman invaders of England established castles for both defensive purposes and to pacify the country's inhabitants [6]. Between 1066 and 1087, the number of 36 castles was established in the English Midlands which used to guard against rebellion [7,8].

Towards the end of the Middle Ages, castles tended to lose their military significance due to the advent of powerful cannons and permanent artillery fortifications [9]. As a result, castles became more important as residences and statements of power [10]. A castle could act as a stronghold and prison but was also a place where a knight or lord could entertain his peers [11]. Over time the aesthetics of the design became more important, as the castle's appearance and size began to reflect the prestige and power of its occupant. Comfortable homes were often fashioned within their fortified walls. Although castles still provided protection from low levels of violence in later periods, eventually they were succeeded by country houses as high status residents [12]. 
In Anatolian, the emperor, commander, lord pavilions with castles were called as "fortress"; thick defence walls surrounding the cities were called "body", "bâru", "city walls"; a tower of triangle, rectangle, polygon, oval protrusions were called "bush", "tower". Ishakpaşa Palace and Hoşap Castle can be displayed as an original sample of Turkish fortress in eastern Anatolian. Karahisar, Karacahisar, Akhisar, Koçhisar, Uçhisar, Eskihisar, Sivrihisar, Seferihisar, Koyulhisar, Yarhisar, Çavdarhisar, Köprühisar were the first important ones. Anatolian defence structures were based on the binary system in Seljuk era: either two nested fortified castle was built on a hill overlooking to the city or "içkale" would rise in the middle or in a corner of the surrounding walls as the last defence point.

The cities were situated in front of the castle walls and around castle wall foot with their ditches. The oldest masters of castle architecture established the Hittites defensive towers in Alacahöyük around Boğazköy which are the most authentic city wall. Urartians were also built some defence samples in Van river basin such as Tuşpa (Van), Çavuştepe, Anzavurtepe, Anzaf Castles. Following castles, city walls were built intensively in and around the Anatolia in Hellenistic, Roman and Byzantine eras. Seljuks and Beyliks were the last in castle architecture with their magnificent defensive structures such as castles and walls in urban periphery based on 3.000 years old architectural heritage [13].

Town walls and towers with attentive stone structures that established on the river coasts and plains were notable and visible due to the topographic location. Even if the castles and town walls were no longer needed in Anatolia in Ottoman era, existing castles and town walls were preserved with regulations between 1839 and 1876. In this period Tokat, Amasya, Sivas, Ankara castles have become vital. Remnants of the old town walls, bastions, gates belt, based on the foundations of the Roman and Byzantine were well preserved in many Ottoman towns [13].

\subsection{Walled towns}

A walled town is a settlement built adjacent to or surrounding a castle. Walled towns, particularly fortresses, were generally small, because walls were expensive to construct, maintain and defend and were therefore kept to a minimum length, preferably circular, enclosing a compact urban area. They were unlikely to possess a varied range of urban functions and facilities and therefore having only a very limited range of economic development once the garrison is removed [14].

By their involvement with heritage, urban, cultural and 'relocated' tourisms, walled historic towns, so well-defined themselves, may help to develop and reinforce definitions of the heritage tourism as explored in the work of the originators of many academic studies [14-20].

\subsubsection{Anatolian castles and city walls}

The word "castle" in Turkish is "kale", meaning the defensive structure built on top of the hill. Many of the towns which have become synonymous with "kale" are widespread in Anatolia such as Çanakkale, Kırıkkale, Akçakale, Toprakkale, Hasankale, Rumkale. The word "fort" was used for fortified castles and fortresses as a phrase which means to keep or surround a place. Best examples of Turkey's Middle Ages defence structures are Anatolia and Rumeli Fortresses on both sides 
of Bosphorus (15 ${ }^{\text {th }}$ century) and Seddülbahir and Kilitbahir castles on Dardanelles ( $17^{\text {th }}$ century). Commercial and residential districts just outside of the city walls were often called as "tahtakale" [13].

\subsubsection{European Walled Towns (EWT)}

The European Walled Towns (EWT) is an international association for sustainable development of walled towns, walled cities and fortified historic towns in Europe. EWT aims to promote the many mutual interests shared by walled towns; wishes to maintain and strengthen the historic walled towns for future generations by applying for European funding and partaking in European projects. The main objectives EWT are: exchange knowledge and experience in many fields, promote the interest of our members, support walled towns and their history in present day functioning, acquire European and other funds, set up projects together to stimulate exchange, enlarge the network of the members, convene regular symposia in member towns [21].

\subsection{Walled towns as cultural landscapes}

Cultural landscapes are at the interface between nature and culture, tangible and intangible heritage, biological and cultural diversity. They represent a closely woven, net of relationships and the essence of culture and people's identity. Cultural landscapes are a focus of protected areas in a larger ecosystem context, and they are a symbol of the growing recognition of the fundamental links between local communities and their heritage, humankind and its natural environment [22].

There are some functional typologies of the cultural landscapes such as: historical townscapes, historical sacred landscapes, paleocultural sacred landscapes, paleocultural townscapes, historical landscapes of rural and nondifferentiated settlements, historical ethno-cultural landscapes, historical palace and park landscapes, historical agricultural landscapes, historical industrial landscapes, paleocultural landscapes of non-differentiated settlements, historical fortification landscapes, memorial associative landscapes, traditional economic, engineering, paleocultural fortification, paleocultural, agricultural, paleocultural industrial landscapes, historical roads, etc. [23]. According to above mentioned definitions, walled towns can best fit and be evaluated in the context of historical fortification landscapes as cultural landscapes.

There are 97 walled towns inscribed in the World Heritage List as cultural heritage. They are the unique examples for the modification of the natural environment into fortification of defensive actions and often represent a masterpiece of human creative genius with large buildings in landscape scale and therefore fit well to cultural landscape category.

\subsubsection{EWT walled towns in Turkey}

There are 550 castles and walled towns in Anatolia of which 8 fortified walled town are in EWT list, namely Diyarbakır, Kütahya, Alanya, Osmangazi, Bursa, Eğirdir, Gaziantep, Karadeniz Ereğli. Here Bursa and Gaziantep walled towns are chosen with special cultural interest in terms of historical background. 


\section{Bursa City Walls}

Bursa was formed by the Bithynians in the 2nd century BC who came and settled to the area in the 7th century $\mathrm{BC}$ and later on became an independent kingdom in 327BC. With the suggestion of General Hannibal who escaped the Romans and took refuge in Bithynia, the Bithynia King Prusias built a city he named Prusias and Olympum in $185 \mathrm{BC}$ on top of a hill and surrounded it with walls. Over time, the city's name Prusias became Prusa and later on Bursa. Built by the Bithynians, the Bursa Castle suffered destructions during various sieges over time and has undergone several repairs during the Roman, Byzantine and the Ottoman eras. During the Orhan Gazi era who added Bursa to the lands of Ottoman Empire in 1326, the walls were supported by bastions (towers). Famous Ottoman traveller, Evliya Celebi who visited Bursa in 1640 stated that the castle had 67 towers, 5 gates and that the surrounding area had 10,000 steps. The walls are approximately 2 kilometres long [21].

\section{Gaziantep Castle}

Gaziantep Castle, an important heritage was built on natural rock faces both on the North and North-East part of a hill called "Kudret" about 25 meters. Archaeological excavation showed that the site has been inhabited from Iron Age 650 BC till Chalcolite Age 5500 BC. Traces of the castle were estimated to date Hittites. However main castle was first built in the $2^{\text {nd }}$ and $3^{\text {rd }}$ century AD in the Roman era and further enlarged and strengthened in Byzantium era by Emperor Justinianus between 527 and 565 AD [21].

\subsection{Alanya walled town}

Alanya, formerly Alaiye, is located on a peninsula into the Mediterranean Sea below the Taurus Mountains (Figure 1), which was a local stronghold for many Mediterranean-based empires, including the Ptolemaic, Seleucid, Roman, Byzantine, and Ottomans. Alanya Castle was a Seljuk era citadel dating from 1226 and accordingly the city's greatest political importance came by Seljuks in the Middle Ages with city's landmarks, as Kizıl Kule (Red Tower), Tersane (Shipyard), and the Castle itself.

Inside the walls of Alanya Castle there are numerous historic villas; well preserved examples of the classical period of Ottoman architecture, most built in the early 19th century as well as Süleymaniye mosque and caravanserai, built by Suleiman the Magnificent [25].

The Kizil Kule (Red Tower) an important section of the castle has been a unique landmark of Alanya. The 108-foot (33 m) high brick building stands at the harbour below the castle, and contains the municipal ethnographic museum. Sultan Kayqubad $1^{\text {st }}$ brought the accomplished architect Ebu Ali from Aleppo, Syria to Alanya to design the building [26]. An octagonal structure consists of 83 towers, specifically protected the Tersane (dockyard) which remains one of the finest 


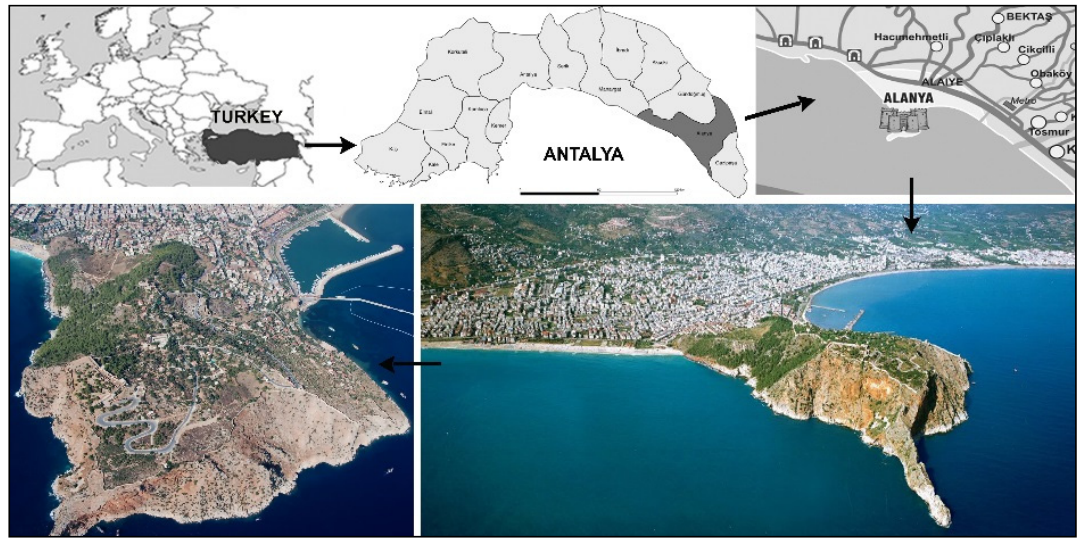

Figure 1: Location of Alanya and Alanya castle [37].

examples of medieval military architecture [27]. With its rich architectural heritage, Alanya is a member of the Norwich-based European Association of Historic Towns and Regions [28]. Since 2009, Alanya Castle and Tersane is on UNESCO World Heritage Sites Tentative List [29, 30] (Figure 2).
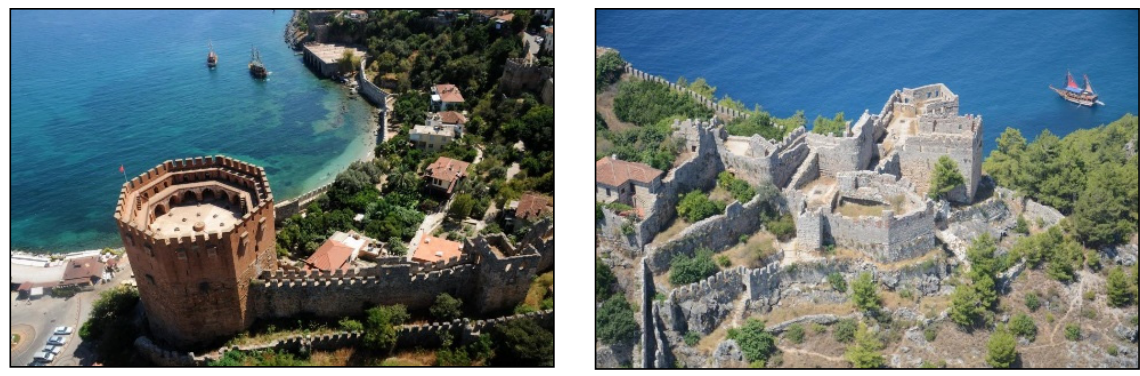

Figure 2: Alanya Castle [31].

Regarding the heritage conservation and need for understanding walled towns as defensive cultural landscapes, different dimensions of cultural landscape were evaluated to comprehend dynamic relationship between nature and walled town of Alanya. The methodological approach of this study is based on Washer (2002), Gomez-Sal et al. (2003), Antrop (2005), ICOMOS (1999), Lörzing (2005), Atik and Işılılı (2007) (Table 1).

\section{Results}

Walled towns have always played a critical role in shaping the identities and images of the communities they embrace [35] and the cities and regions they located in. With regard to UNESCO's criteria for world heritage sites, walled 
Table 1: An evaluation of Alanya Walled Town with its ecological, cultural, economic and social landscape dimensions.

\begin{tabular}{|c|c|c|}
\hline $\begin{array}{l}\text { Landscape } \\
\text { Dimensions }\end{array}$ & Content & Alanya Walled Town \\
\hline Ecological & $\begin{array}{l}\text { The ecological dimension } \\
\text { presents the dynamic } \\
\text { relationship between natural } \\
\text { landscape factors such as soil, } \\
\text { flora, etc. and helps us to } \\
\text { understand the content of the } \\
\text { landscape. } \\
\text { There is a general recognition } \\
\text { that the dimension of ecology } \\
\text { effect to and are affected by } \\
\text { dynamic relationship of } \\
\text { ecosystems. In this sense, } \\
\text { ecological dimension of } \\
\text { landscape is used by } \\
\text { integrating work of planning, } \\
\text { management and protection } \\
\text { will improve our life with an } \\
\text { objective approach and } \\
\text { provide an understanding of } \\
\text { landscape content [32] }\end{array}$ & $\begin{array}{l}\text { Alanya Castle, referred as } \\
\text { Koracesium, Klanoros meaning } \\
\text { beautiful mountain and Alaiyye is } \\
\text { located at the southern part of the city } \\
\text { over a peninsula } 250 \text { meters above the } \\
\text { sea level. The peninsula, surrounded } \\
\text { with walls is } 10 \text { hectares in size and } \\
\text { used throughout the history as } \\
\text { settlement and for defence due to its } \\
\text { suitable location. The wall which } \\
\text { surrounds the castle is } 6.5 \text { kilometres } \\
\text { long and includes } 140 \text { towers and } \\
\text { open green areas. Alanya Castle and } \\
\text { its surrounding is home for many } \\
\text { plants and wildlife species. About } 322 \\
\text { plant species, } 29 \text { insects and } 31 \\
\text { butterflies were already identified in } \\
\text { and around the castle of which } 117 \\
\text { plants and number of insects including } \\
20 \text { endemics are in a Herbarium } \\
\text { Exhibition Museum next to Red } \\
\text { Tower [33]. Alanya Castle and its } \\
\text { green areas are contributing to } \\
\text { develop and sustain urban ecology and } \\
\text { urban landscape with plant and } \\
\text { wildlife species also for Alanya City. }\end{array}$ \\
\hline Cultural & $\begin{array}{l}\text { Monuments, sacred buildings, } \\
\text { historical elements and } \\
\text { natural and cultural structures } \\
\text { with all traces of social and } \\
\text { economic activities represent } \\
\text { dimension of cultural heritage } \\
\text { and landscape. } \\
\text { Examination of the historical } \\
\text { structure, public custom and } \\
\text { traditions and identity are } \\
\text { important on understand } \\
\text { heritage value of cultural } \\
\text { landscapes. Often historic } \\
\text { ruins, religious buildings, } \\
\text { houses, bridges, castles, etc. } \\
\text { build a common ground into } \\
\text { the future. }\end{array}$ & $\begin{array}{l}\text { Alanya walled town has } 2400 \text { years } \\
\text { history and a kind open air museum in } \\
\text { a cultural landscape setting mainly } \\
\text { with Seljuk monuments such as the } \\
\text { Red Tower, Shipyard, Armory but } \\
\text { also monuments and defence buildings } \\
\text { from different eras. Some of them are } \\
6 \mathrm{~km} \text { long walls, } 140 \text { bastions, } 400 \\
\text { cisterns, magnificent gates with } \\
\text { inscriptions and decorations, churches } \\
\text { located in İç Kale (Citadel) and } \\
\text { Tophane (Armory) Quarters, ruins of } \\
\text { Byzantine monasteries located at Cape } \\
\text { Cilvarda, monuments of the Ottoman } \\
\text { era such as the Süleymaniye Mosque, } \\
\text { Khan and Arasta and some more } 200 \\
\text { examples of civil architecture. }\end{array}$ \\
\hline
\end{tabular}


Table 1: Continued.

\begin{tabular}{|c|c|c|}
\hline $\begin{array}{l}\text { Landscape } \\
\text { Dimensions }\end{array}$ & Content & Alanya Walled Town \\
\hline Economic & $\begin{array}{l}\text { Human activities on } \\
\text { landscape, orientations to } \\
\text { productions and economy are } \\
\text { effective in the development } \\
\text { as well as the change in the } \\
\text { landscape. Human efforts to } \\
\text { benefit from the nature reflect } \\
\text { to use of landscape for } \\
\text { economic and politic } \\
\text { purposes. Major sectors of a } \\
\text { region are based on economic } \\
\text { relations and the distribution } \\
\text { of population. }\end{array}$ & $\begin{array}{l}\text { Alanya (Alaiye) has been one of the } \\
\text { major ports of the eastern } \\
\text { Mediterranean that fund in } 65 \mathrm{BC} \\
\text { throughout history safely sheltered } \\
\text { from winds and waves. It was not only } \\
\text { an important military and defensive } \\
\text { role bout also a crucial commercial } \\
\text { centre of its time that dominated the } \\
\text { regional economy of its time. Harbour } \\
\text { below the castle and Tersane } \\
\text { (Shipyard) were the important sections } \\
\text { where economic activities took place } \\
\text { most. } \\
\text { Today Alanya is one of the most } \\
\text { important tourist resorts in the region } \\
\text { of Antalya and Turkey. Tourism } \\
\text { attraction of the city is based on } \\
\text { Alanya Castle with historical } \\
\text { background related to Hellenistic, } \\
\text { Roman, Byzantine, Seljuk and } \\
\text { Ottoman eras [34]. }\end{array}$ \\
\hline Social & $\begin{array}{l}\text { To encourage individuals and } \\
\text { communities to take } \\
\text { initiatives over their inherited } \\
\text { cultural and natural resources } \\
\text { and properties and to build } \\
\text { and advance a positive } \\
\text { relationship between local } \\
\text { people and surrounding } \\
\text { landscape. } \\
\text { This in return would promote } \\
\text { a life quality of the host } \\
\text { communities and also would } \\
\text { support social dimensions in } \\
\text { landscape. }\end{array}$ & $\begin{array}{l}\text { Alanya Walled Town exhibited social } \\
\text { and cultural structure which is } \\
\text { combined by Hellenistic, Roman, } \\
\text { Byzantine, Seljuk and Ottoman } \\
\text { periods. The current castle was built } \\
\text { over existing fortifications and served } \\
\text { a double purpose of a palace of local } \\
\text { government and as a defensive } \\
\text { structure. In 2007, the city began } \\
\text { renovating various sections of the } \\
\text { castle, including adaptation of a } \\
\text { Byzantine church for use as a } \\
\text { Christian community centre [24]. } \\
\text { Inside the castle is the Süleymaniye } \\
\text { mosque, caravanserai and a } \\
\text { community centre [25]. }\end{array}$ \\
\hline
\end{tabular}

towns as cultural landscapes are well fit is the criteria (iv) 'an outstanding example of a type of building, architectural or technological ensemble or landscape which illustrates significant stage(s) in human history' [36]. They exhibit traces of the cultural heritage and landscape features with outstanding universal values as they masterfully integrated into the natural landscape. 
In the paper we tried to evaluate and understand Alanya Walled Town as a defensive cultural landscape with a multidimensional approach. Alanya Walled Town is a member of European Association of Historic Towns and Regions and in the UNESCO World Heritage Tentative List since 2009, which reflects a historical peninsula settlement of $13^{\text {th }}$ century. There are 83 towers, 140 bastions and also a Citadel at the top of the peninsula which has been an outdoor museum. Particularly Kizil Kule (Red Tower) has been a unique cultural landmark of Alanya.

Different conservation approaches play an important role to protect and to transfer cultural landscapes to the future generations. ICOMOS (International Council on Monuments and Sites), UNESCO, ÇEKÜL, Historical Towns, Historical Walled Towns Association in Turkey are organisations that related with the protection of historical sites and walled towns in particular.

Alanya Castle has been declared as natural, archaeological and urban conservation area in 1999 by The Council of Cultural and Natural Heritage Conservation of Turkey. Although it was typically a defensive cultural landscape, today cultural values of Alanya Castle on an ecological setting have become major characteristics. However according to a multidimensional approach implicated in this study a set of conclusions for Alanya Castle can be made as below;

- From an ecological point of view Alanya Castle was best harmonised with coastal geography on a Mediterranean peninsula which can be regarded as integrated relationship with the natural environment and sustainable land use patterns.

- The ecological dimension of Alanya Castle supports the biological systems and habitats. Species diversity in the flora and flora is quite high with 322 plant species, 29 insects and 31 butterflies some of which are endemics.

- From a cultural point of view the castle itself and Tersane (dockyard) in particular are recognisable architectural artefacts defined as one of the finest examples of medieval military architecture in the Mediterranean.

- Sericulture was a way of living and cultural life in the settlements in the castle and today traditional silk and cotton textile has been symbolically demonstrated in wood and stone houses as inherited cultural heritage.

- From economic point of view Alanya Castle and harbour was an important political commercial maritime centre of trade and shipping dominating regional economy of its time.

- Today, Alanya Castle is the main tourism attraction in the Alanya province which is the most important tourist resorts in the region of Antalya.

- From social point of view Alanya walled town was home for different cultures throughout history in Hellenistic, Roman, Byzantine, Seljuk and Ottoman eras. Recently a Byzantine church in the castle was restored as a Christian community centre.

Walled towns tend to preserves in an intact and visible form many traces - in terms of architecture, urban design and integrated relation with natural environment. However according to Stephenson (2008) there is a growing awareness of the need to sustain cultural diversity and ecological diversity and aesthetic character in the heritage protection under the World Heritage 
Convention. A multidimensional approach evaluated in this study can communicate deeper insight about cultural landscapes and their heritage values and can be a helpful tool for their integrated management and protection.

\section{References}

[1] Creighton, Oliver; Higham, Robert, 2003. Medieval Castles, Shire Archaeology, ISBN 0-7478-0546-6

[2] Cathcart King, David James, 1988. The Castle in England and Wales: an Interpretative History, London: Croom Helm, ISBN 0-918400-08-2

[3] Coulson, Charles, 2003. Castles in Medieval Society: Fortresses in England, France, and Ireland in the Central Middle Ages, Oxford: Oxford University Press, ISBN 0-19-927363-4

[4] Liddiard, Robert, 2005. Castles in Context: Power, Symbolism and Landscape, 1066 to 1500, Macclesfield: Windgather Press Ltd, ISBN 09545575-2-2

[5] Herlihy, David, 1970. The History of Feudalism, London: Humanities Press, ISBN 0-391-00901-X

[6] Friar, Stephen, 2003. The Sutton Companion to Castles, Stroud: Sutton Publishing, ISBN 978-0-7509-3994-2

[7] Liddiard, Robert, 2005. Castles in Context: Power, Symbolism and Landscape, 1066 to 1500, Macclesfield: Windgather Press Ltd, ISBN 09545575-2-2

[8] Stephens, W.B. (ed), 1969. "The castle and castle estate in Warwick", A History of the County of Warwick 8

[9] Duffy, Christopher, 1979. Siege Warfare: The Fortress in the Early Modern World 1494-1660, London: Routledge \& Kegan Paul, ISBN 0-7100-8871$\mathrm{X}$

[10] Duffy, Christopher, 1979. Siege Warfare: The Fortress in the Early Modern World 1494-1660, London: Routledge \& Kegan Paul, ISBN 0-7100-8871$\mathrm{X}$

[11] Cathcart King, David James, 1983. Castellarium Anglicanum: An Index and Bibliography of the Castles in England, Wales and the Islands. Volume I: Anglesey-Montgomery, London: Kraus International Publications, ISBN 0-527-50110-7

[12] Liddiard, Robert, 2005. Castles in Context: Power, Symbolism and Landscape, 1066 to 1500, Macclesfield: Windgather Press Ltd, ISBN 09545575-2-2

[13] Sakaoğlu, N., 2008. Kaleler ve şehir surları. Tarihi Kentler Birliği Dergisi, Yerel Kimlik Sayı: 14, s.22-25. İstanbul.

[14] Ashworth, G. and David M. Bruce, D., M., 2009. Town walls, walled towns and tourism: paradoxes and paradigms, Journal of Heritage Tourism, 4:4, 299-313, DOI: 10.1080/17438730903118097

[15] Ashworth, G.J., \& Tunbridge, J.E., 2000. The tourist-historic city: Retrospect and prospect of managing the heritage city. London: Belhaven. 
[16] Boyd, S.W., 2002. Cultural and heritage tourism in Canada: Opportunities, principles and challenges. Tourism and Hospitality Research, 3(3), 211233.

[17] Fyall, A., \& Garrod, B., 1998. Heritage tourism: At what price? Managing Leisure, 3(4), 213-228.

[18] Lowenthal, D., 1966. Possessed by the past: The heritage crusade and spoils of history. New York: The Free Press.

[19] Timothy, D.J., 1997. Tourism and personal heritage experience. Annals of Tourism Research, 24(3), 751-754.

[20] Tunbridge, J.E., \& Ashworth, G., 1996. Dissonant heritage: Managing the past as a resource in conflict. Chichester: Wiley.

[21] EWT, 2014. Constitution, http://walledtowns.com/over-ons/developmentplan/.23.01.2014

[22] Rössler, M., 2006. World Heritage Cultural Landscapes: A UNESCO Flagship Programme 1992 - 2006. Landscape Research, Vol. 31, No. 4, 333-353, October 2006.

[23] Kuleshova, M., 2007. Cultural Landscapes in the World Heritage List. Heritage Institute, Moscow, Russia.

[24] “Ancient Church needs support". Orange Alanya. April 15, 2007. Retrieved May 2, 2009.

[25] Alanya'nın Resmi Web Sites. 2007. Archived from the original on 8 August 2008. Retrieved September 7, 2008.

[26] Alanya Cities and Historical Sites. Turkish Class. 2007. Archived from the original on 6 October 2008. Retrieved September 7, 2008.

[27] Dörner, F. K.; L. Robert; Rodney Young; Paul A. Underwood; Halet Çambel; Tahsin Özgüç; A. M. Mansel; A. Gabriel (1954). "Summary of Archaeological Work in Turkey in 1953". Anatolian Studies 4: 13-20. doi: 10.2307/3642371. JSTOR 3642371.

[28] Association of Historic Towns of Turkey. European Association of Historic Towns and Regions. Archived from the original on 10 September 2008. Retrieved September 7, 2008.

[29] Hürriyet Daily News, 2009. "Alanya in line for 'World Heritage' tag". February 4, 2009. Retrieved February 5, 2009.

[30] Today's Zaman, 2009. "5 more sites from Turkey on UNESCO's World Heritage Tentative List “. April 24, 2009. Archived from the original on 26 April 2009. Retrieved April 24, 2009.

[31] Alanya Municipality, 2013. Tarihçe. http://alanya.bel.tr/Sayfa/10/Tarihce. 23.01.2014.

[32] Deniz, B., Küçükerbaş, E.V., Tunçay, H. E., 2006. Peyzaj Ekolojisine Genel Bakış. Adnan Menderes Üniversitesi Ziraat Fakültesi Dergisi 2006, 3(2), Aydın. Sayfa 5-18.

[33] Anonymous, 2013. http://www.kanalalanya.com/alanyaHaber/?menuID= 434\&ContentID $=11620 \& I D=1$ 1620\&MenuType $=131 \&$ lang $=45 \&$ ex $=$ detai 1/detail.asp.

[34] Sayan, S., 2001. Antalya'nın Doğal ve Kültürel Peyzaj Özelliklerine Genel Bir Bakış. Anatolia Turizm Araştırmaları Dergisi, Cilt: 12, Sayı: 1, s.57-67. 
[35] Bruce, D. and Creighton, O. H. 2006. Contested identities: the dissonant heritage of European town walls and walled towns. International Journal of Heritage Studies, 12(3): 234-54.

[36] UNESCO, 2008. Culture. http://portal.unesco.org/culture/en/ev.php-

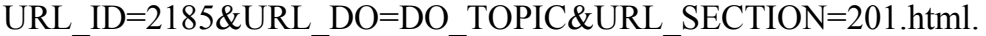

[37] Stephenson, J., 2008. The Cultural Values Model: An integrated approach to values in landscapes. Landscape and Urban Planning, 84:127-139.

[38] Anonymous, 2014. Alanya. http://www.guzelyalihomes.com/en/alanya-29. 